NBER WORKING PAPER SERIES

\title{
FOREIGN PARTICIPATION IN LOCAL CURRENCY BOND MARKETS
}

\author{
John D. Burger \\ Francis E. Warnock \\ Working Paper 12548 \\ http://www.nber.org/papers/w12548
}

\author{
NATIONAL BUREAU OF ECONOMIC RESEARCH \\ 1050 Massachusetts Avenue \\ Cambridge, MA 02138 \\ September 2006
}

The authors thank William Griever, Thomas Jans, and Denis Petre for invaluable assistance with data; JP Morgan for providing data on bond returns; and Jillian Faucette, Tamara Hayford, and Sara Holland for research assistance. We also thank for helpful comments David Cushman (the editor), Morris Goldstein, Bill Helkie, Olivier Jeanne, Steve Kamin, Ross Levine, Ugo Panizza, Vincent Reinhart, Charles Thomas, Joachim Voth, Jon Wongswan, and seminar participants at Trinity College International Bond and Debt Market Integration Conference, Berkeley Conference on Global Imbalances and Asian Financial Markets, Darden Conference on Investing in Emerging Markets, CEPR/Gerzensee Conference on International Capital Flows, IF Monday Workshop, IMF Research Seminar, Loyola College, and University of North Carolina. All errors are our own. We acknowledge generous support from the Sellinger School Junior Sabbatical Program (Burger ) and the Darden School Foundation (Warnock). The views expressed herein are those of the author(s) and do not necessarily reflect the views of the National Bureau of Economic Research.

(C)2006 by John D. Burger and Francis E. Warnock. All rights reserved. Short sections of text, not to exceed two paragraphs, may be quoted without explicit permission provided that full credit, including $\odot$ notice, is given to the source. 
Foreign Participation in Local Currency Bond Markets

John D. Burger and Francis E. Warnock

NBER Working Paper No. 12548

September 2006

JEL No. F3, G11, G15, O16

\begin{abstract}
Countries that cannot attract foreigners to invest in their local currency bonds run the risk of currency mismatches that can result in painful crises. We analyze foreign participation in the bond markets of over 40 countries. Bond markets in less developed countries have returns characterized by high variance and negative skewness, factors that we show are eschewed by U.S. investors. While results based on a three-moment CAPM indicate that it is diversifiable idiosyncratic risk that U.S. investors shun, our analysis suggests that countries can improve foreign participation by reducing macroeconomic instability.
\end{abstract}

John D. Burger

Loyola College in Maryland

4501 N. Charles Street

Baltimore MD 21210-2699

jburger@loyola.edu

Francis E. Warnock

Darden Business School

University of Virginia

Charlottesville, VA 22906-6550

and NBER

warnockf@darden.virginia.edu 


\section{Introduction}

The ability to attract foreign participation in local currency bond markets has important benefits for industrial and developing economies alike. Two examples forcibly make this point. In the United States, foreign participation in the Treasury market has helped keep U.S. interest rates relatively low despite anemic U.S. savings rates (Warnock and Warnock, 2005). At the other end of the spectrum are developing economies, which presumably have a greater need for foreign capital but are unfortunately unable to attract foreign investors to their local currency bonds. This inability to attract foreign investors has led to a reliance on foreign-currency-denominated debt (Eichengreen and Hausmann, 2005; Burger and Warnock, 2006) and a concomitant currency mismatch that has been linked to the increased likelihood and severity of financial crises (Goldstein and Turner, 2004).

In this paper, we analyze the ability of countries to attract international investors to their local bond markets. Data on all foreigners' investment in local bond markets do not exist, so we rely on high-quality data on the cross-border holdings of one of the largest groups of international bond investors, U.S. investors. The data reveal very limited participation by U.S. investors in local currency bond markets overall, and especially limited in emerging markets. But there is significant cross-country variation, which leads us to investigate factors influencing U.S. investor portfolio decisions. We follow work by Kraus and Litzenberger (1976), Athayde and Flores (2004), and Harvey, Liechty, Liechty, and Muller (2003) and sketch a model in which investors care about the mean, variance, and skewness of returns. The model predicts that if these characteristics are priced with respect to the U.S. investor, country weights in U.S. investors' international bond portfolios should be a function of bond market capitalizations and direct barriers to international investment. 
To the contrary, we find evidence that U.S. investors avoid local-currency bonds that have returns with historically high variance and negative skewness. Decomposing these risks, we find that U.S. investors are avoiding diversifiable idiosyncratic risk, yet another indication of the home bias in portfolios.

Our finding that U.S. investors fail to diversify fully and avoid the most volatile bond markets represents a challenge for emerging economies. The unsavory returns characteristics in emerging markets are most likely tied to macroeconomic instability. Burger and Warnock (2006) demonstrate that improved macroeconomic policies increase the ability to issue bonds in local currency. The results in this paper suggest the same policies will attract greater foreign participation.

\section{Risk and Return Characteristics of International Bond Portfolios}

We are interested in understanding the extent to which global investors' cross-border holdings of local currency bonds varies across countries. Portfolio theory predicts internationally diversified portfolios, but it is well known that investors tend to exhibit a bias toward local or domestic securities. ${ }^{1}$ Because the benefits of international diversification accrue through the returns characteristics of foreign securities, we begin this exploration by characterizing risk and returns in foreign bonds.

Not knowing the extent to which international bond positions are hedged, we form two sets of returns, each from the perspective of a U.S.-based investor. The first, Unhedged, is comprised of unhedged local-currency bonds for developed countries. For emerging

\footnotetext{
${ }^{1}$ Much of the extensive home bias literature has focused on international equities (see the surveys by Karolyi and Stulz (2003) and Lewis (1999)), but there is also a small literature on the potential diversification gains from holding international bonds (Levy and Lerman (1988), Jorion, (1991), and Levich and Thomas (1993), among others).
} 
markets, where local-currency bond indices have not generally been available, Unhedged is the sum of currency returns and bond returns from J.P. Morgan's Emerging Market Bond Index (the EMBI is composed of dollar-denominated bonds). Our second set of returns, Hedged, is comprised of hedged bonds for developed countries and returns on dollardenominated bonds for emerging markets. ${ }^{2}$

For the 41 countries for which we were able to obtain historical returns data, Table 1 presents statistics on the mean, variance, and skewness of hedged and unhedged historical returns over the period from January 1998 to December $2001 .^{3}$ Two features of returns stand out. First, for developed country bonds, hedged returns are much less volatile than unhedged returns, but unhedged bonds provide a more attractive skewness profile. Second, compared to developed bond markets, emerging economy bond markets are much more volatile and exhibit significantly more negative skewness. We discuss these features next.

\subsection{Developed Countries: Characteristics of Hedged and Unhedged Returns}

For developed country bonds, a comparison of hedged and unhedged returns indicates that hedged returns were much higher (6.9\% per year vs. $0.7 \%)$ and much less volatile $(0.017$ vs. 0.140$)$. The higher return that hedged foreign bonds provided U.S. investors is clearly sample-dependent; unhedged returns were weighed down by the dollar's bull run through December 2001. But the fact that unhedged returns are much more volatile than hedged returns, on average by a factor of eight, is not sample-dependent. From the perspective of a U.S.-based investor, unhedged returns are comprised of returns on the

\footnotetext{
${ }^{2}$ Recently, some emerging market local currency bond indices have been started, but they are very recent and hence do not have sufficient history to be included in this study. The reader should note that our Hedged series for emerging markets does not include hedging costs, which may be prohibitively high.

3 The returns data we use are from various JPMorgan bond indexes (GBI, EMBI Global, and JACI). We end our sample in December 2001 to correspond with the holdings data from U.S. benchmark surveys, which we analyze in Section 3. Six countries are included but have somewhat shorter returns series (start date in parentheses): Indonesia, India, and Hong Kong (Jan. 1999); Hungary (Feb. 1999); Chile (June 1999); and Singapore (Jan. 2000).
} 
underlying bond and on the foreign currency; the latter component, foreign currency returns, is notoriously volatile. ${ }^{4}$

Although hedged bonds dominated unhedged bonds in a mean-variance sense during this period, unhedged bonds provided a more attractive skewness profile. The unhedged returns of every developed country bond market (except for Sweden's) exhibited positive skewness, while for most countries hedged returns were negatively skewed. A plausible explanation of this relationship is that in months when developed country bonds experience a large negative return, the currency appreciates and eliminates the infrequent bad outcome for a U.S.-based investor. The case of Japan, with the largest negative skewness among hedged returns for developed countries, is instructive. In December 1998, long-term interest rates in Japan surged following the announcement of various fiscal stimulus measures. U.S. investors holding a hedged portfolio of Japanese bonds experienced a substantial $5 \%$ loss during the month; hence, the negative skewness. But a simultaneous appreciation of the yen generated by capital inflows enabled U.S. investors holding unhedged Japanese bonds to earn a positive return in dollar terms. More generally, this relationship is evidence that we do not see "flight-from-quality" in developed country capital markets. Bond returns might at times be negative, and sometimes severely so, but this does not tend to coincide with broad-based capital outflows and, hence, is not associated with currency depreciations.

\subsection{Returns Characteristics of Less Developed Bond Markets}

The second regularity is that returns on emerging market bonds were much more volatile and exhibited significantly more negative skewness than developed country bonds, whether returns are assumed to be hedged or not. The average variance for unhedged

\footnotetext{
${ }^{4}$ Were there a negative covariance between currency and bond returns, the variance of unhedged foreign currency positions would be somewhat reduced (Levich, 2001).
} 
emerging market bond returns was 0.8 , nearly six times greater than the developed country bond returns, and the average skewness was negative (-0.95). Returns on hedged emerging market bonds were also very volatile and negatively skewed. The higher variance and more negative skewness of less developed bond markets highlights a distinct difference between emerging market and developed country bonds: Periods of negative bond returns for emerging markets do not coincide with currency appreciations. To the contrary, periods of rising interest rates often occur during an episode of financial flight and currency depreciation - the makings of a currency crisis.

\subsection{Lessons from the Efficient Frontier}

The potential for returns characteristics to impact foreign participation in local currency bond markets is further demonstrated by the efficient frontier in Figure 1. The efficient frontier depicts the risk-return profiles of hedged (dashed line) and unhedged (solid line) bond portfolios for the period from January 1994 to December 2001. On each line, portfolios vary from 100 percent U.S. bonds (at the end labeled 'US') to 100 percent foreign bonds (at the end labeled 'ROW'). Figure 1 shows that, even for developed countries, attracting cross-border investment in local currency bonds is likely impeded by the significant unrewarded currency risk facing foreign investors. From the perspective of a U.S. investor, adding unhedged foreign bonds significantly increases portfolio risk. ${ }^{5}$ The figure is also suggestive of gains to diversification from adding hedged foreign bonds, which over this period reduced portfolio risk. Investors will therefore likely prefer crossborder positions where the currency risk can be hedged.

\footnotetext{
${ }^{5}$ The mean-variance tradeoffs for various holding periods starting from 1988 and ending in 2001 (not shown) are very similar. The evidence from an earlier period is similar; for 1977-1990, Levich and Thomas (1993) find that currency volatility more than outweighed the increased returns and the optimal (ex post) unhedged bond portfolio would have been composed mainly of U.S. bonds.
} 


\section{Foreign Participation in Local Bond Markets}

In this section we analyze the extent and determinants of foreign participation in local bond markets. We first present the country allocation of U.S. investors' international bond portfolios, and compare that allocation with the composition of the world bond market portfolio. This shows that U.S. investors severely underweight foreign bonds overall—and the bonds of some countries more than others. We then present a simplified mean-varianceskewness model that informs our regressions on deviations from world portfolio weights.

We include in this section data on U.S. holdings of the local currency bonds of 48 countries, every country for which we were able to obtain data on the size of the local bond market. The data on U.S. holdings, which (like the bond market data) include the holdings of both corporate and sovereign bonds, come from the comprehensive benchmark survey of U.S. investment abroad as of December 2001 (Table 16 of Department of Treasury et al., 2003). The bond market data are discussed in detail in Burger and Warnock (2006). ${ }^{6}$

\subsection{Comparison of U.S. Investors' Foreign Bond Portfolio and the World Market Portfolio}

Table 2 highlights several facts about U.S. investors' foreign bond portfolios. The vast majority ( $\$ 150$ billion) of U.S. holdings of local-currency foreign bonds was issued by developed countries, compared to only $\$ 3$ billion of emerging market bonds. Compared to their weight in the world bond market portfolio $\left(\omega_{\mathrm{m}}=46.96 \%\right)$, local currency bonds have only a very small weight in U.S. investors' bond portfolios $\left(\omega_{\text {us }}=1.2 \%\right)$. This underweighting is best illustrated in the final column, which shows the ratio of weights in U.S. portfolios to weights in the world market portfolio. If allocations in U.S. investors'

\footnotetext{
${ }^{6}$ The positions data are analogous to U.S. data on foreign equity positions used in Ahearne, Griever, and Warnock (2004) and Dahlquist, Pinkowitz, Stulz, and Williamson (2003). For a primer on the benchmark surveys, see Griever, Lee, and Warnock (2001). We do not use Coordinated Portfolio Investment Surveys (CPIS) data compiled by the IMF, because it does not provide essential information on the currency denomination of bond holdings.
} 
bond portfolios were in line with the world bond market portfolio, this ratio would equal one, but it is much less than one for every country. The underweighting is severe in developed countries' bonds $\left(\omega_{u s} / \omega_{\mathrm{m}}=0.029\right)$ and even more so in emerging markets $\left(\omega_{u s} /\right.$ $\left.\omega_{\mathrm{m}}=0.004\right)$. But there are exceptions. For example, the relative weight on South African bonds $\left(\omega_{u s} / \omega_{\mathrm{m}}=0.029\right)$ is greater than the weight on many developed country bonds. In the next subsection, we exploit the variation in relative portfolio weights to analyze the ability of countries to attract investors to their local currency bonds.

\subsection{Historical Returns Characteristics, Capital Account Restrictions, and U.S. Participation}

Table 2 establishes that U.S. investors' foreign bond portfolios deviate substantially from the world market portfolio. In this section we sketch a simple model of portfolio allocation that encompasses two features of international bond markets - barriers to international investment and returns that exhibit higher moments — and use the model to inform cross-sectional regressions of the extent to which U.S. investors' portfolio weights deviate from benchmark (market) weights.

We follow the work of Kraus and Litzenberger (1976), Athayde and Flores (2004), and Harvey, Liechty, Liechty, and Muller (2003) and allow for the fact that asset returns exhibit higher moments and that investors with nonincreasing absolute risk aversion should care about skewness, in particular, in addition to mean and variance. ${ }^{7}$ Specifically, we assume that investors choose a vector of portfolio weights, $\omega$, to maximize utility that is a function of (expected) returns $x$, variance $V_{x}$, and skewness $S_{x}$ :

\footnotetext{
${ }^{7}$ As Kraus and Litzenberger (1976) note, while one could include fourth and higher moments, we lack compelling behavioristic arguments for investor attitudes for those moments.
} 


$$
U\left(\omega, x, V_{x}, S_{x}\right)=\omega^{\prime} x-\lambda \omega^{\prime} V_{x} \omega+\gamma \omega^{\prime} S_{x} \omega \otimes \omega
$$

where $V_{x}=(x-\bar{m})(x-\bar{m})^{\prime}$

$$
\begin{aligned}
& S_{x}=V_{x} \otimes(x-\bar{m})^{\prime} \\
& \bar{m}=\sum_{i=1}^{N} x_{i} / N
\end{aligned}
$$

and $\lambda$ and $\gamma$ are the relative utility weights on variance and skewness, respectively.

Alternatively, investors can determine the optimal portfolio by minimizing variance subject to expected returns (net of costs) and skewness. Analytical solutions to this optimization problem are rather complicated — see Harvey et al. (2003) and Athayde and Flores (2004), who note that feasible solutions can be calculated in most cases—-but take the general form:

$\omega=f\left(\stackrel{+}{x}, \stackrel{-}{V}_{x}, \stackrel{+}{S} x\right)$

where the signs above the arguments indicate that weights should be higher on countries that add to the portfolio's expected returns and skewness and reduce the portfolio's variance.

In an international setting, we must also control for barriers to international investment. For example, we analyze U.S. positions in local-currency bonds, but some countries have capital controls such as restrictions on the repatriation of investment income. Direct barriers to international investment can be modeled by assuming that they impose a cost, $C$, that varies across countries and reduces investors' expected returns. ${ }^{8}$ If , in addition, a separation theorem is invoked [see, for example, Cass and Stiglitz (1970)] and variance and skewness are fully priced, a U.S. investor's optimal allocation can be

\footnotetext{
8 For portfolio allocation models with barriers to international investment, see Black (1974), Stulz (1981), and Cooper and Kaplanis (1986).
} 
represented by a vector of portfolio weights, $\omega_{\text {us }}$, that depends on the vector of world market portfolio weights, $\omega_{\mathrm{m}}$, and the vector of costs from barriers to investment, $C$ :

$\omega_{u s}=f\left(\stackrel{+}{\omega_{m}}, \stackrel{-}{C}\right)$

Our empirical exercise in this section controls for world market portfolio weights and barriers to international investment and tests whether the expected mean, variance, and skewness of returns affect U.S. portfolio allocations. Specifically, we estimate OLS regressions of the following type:

$\frac{\omega_{i, u s}}{\omega_{i, m}}=\alpha_{0}+\alpha_{1}$ Openness $_{i}+\alpha_{2} x_{i}+\alpha_{3} V_{i}+\alpha_{4} S_{i}+\varepsilon_{i}$

where $\omega_{i, \text { us }} / \omega_{i, m}$ is the weight of country $i$ in the U.S. bond portfolio $\left(\omega_{i, u s}\right)$ relative to its weight in the world bond market portfolio $\left(\omega_{i, m}\right)$; Openness $s_{i}$ is an average of the 2000 and 2001 measures of capital account openness from Gwartney et al. (2003), ranging from zero (completely closed) to ten (completely open); and $x_{i}, V_{i}$, and $S_{i}$ are the expected mean, variance, and skewness of returns.

Empirical implementation of this model requires measures of the expected mean, variance, and skewness of returns. For expected mean returns, we allow for the possibility that investors use past returns to forecast future returns, but we also rely on past work indicating that business cycle variables have predictive power for bond returns [Keim and Stambaugh (1986); Chen (1991); and Ilmanen (1995)]. We construct a de-trended real stock 
market variable, Cycle, equal to one if the country's stock market index is at the long-run trend, greater than one if the stock market is above historical trend, and less than one if it is below trend. ${ }^{9}$ Expected bond returns should be high at a cyclical peak; when stock prices are high relative to trend, an economic slowdown might be in the offing, which would allow interest rates to fall and produce higher bond returns. For variance and skewness, evidence suggests that historical averages have sufficient predictive power, at least in the crosssection. Erb, Harvey, and Viskanta (1999) suggest as much by noting the constancy of skewness in emerging market bonds. To confirm that historical averages of variance and skewness are reasonable proxies for expected future values, we calculate rank correlations of historical averages (computed over the 1993-1997 period) with future values (1998). The rank correlations are quite high, 0.67 for historical and future variance and 0.59 for skewness, indicating that historical values are reasonable proxies for expected values. Not surprisingly, the rank correlation for historical and future mean is substantially lower $(0.31)$. With these observations in mind, our working model is the following cross-sectional regression (with country $i$ subscripts omitted):

$$
\frac{\omega_{u s}}{\omega_{m}}=\alpha_{0}+\alpha_{1} \text { Openness }+\alpha_{2} \bar{X}+\alpha_{3} \bar{V}+\alpha_{4} \bar{S}+\alpha_{5} \text { Cycle }+\varepsilon
$$

where $\omega_{u s} \omega_{m}$ is based on end-2001 values, Openness is an average of 2000 and 2001 values, the overbars denote historical values calculated from monthly excess bond returns over the

${ }^{9}$ Cycle, which is defined as $\frac{P_{t}}{\left(P_{t-1}+0.9 * P_{t-2}+0.9^{2} * P_{t-3}+\ldots\right) * 0.1}$, where $\mathrm{P}_{\mathrm{t}}$ is the real value of a country's equity index at time $t$, is the inverse of a measure used by Ilmanen (1995) to forecast one-month ahead bond returns. We assume bond investors have a longer time horizon and therefore offer an alternative interpretation. 
48 month period preceding December 2001, and Cycle is the detrended stock market value as of December 2001. ${ }^{10}$

The empirical results are presented in Table 3 for the 41 countries for which we have complete data. ${ }^{11}$ We lose two more countries (Norway and Switzerland) when we analyze hedged returns. Because New Zealand is an outlier-U.S. investors hold an exceptionally large percentage of the local-currency New Zealand bond market—we report results both with New Zealand [columns (1), (3), (5), and (7)] and without [columns (2), (4), (6), and (8)]. Throughout the table, evidence of returns-chasing behavior — of either past or prospective returns - is scarce; historical returns and Cycle are insignificant in most specifications.

The left panel of Table 3, which assumes that returns are unhedged, indicates an aversion to volatile bond markets. To investigate whether this aversion to volatility carries over in the absence of exchange rate risk, we repeat the exercise using hedged returns in the right panel. Due to a high degree of collinearity between the variance and skewness of hedged returns $(\rho=-0.60)$, in columns (3) - (6) we do not include these risk measures together in the same regression. Columns (3) and (4) report a highly significant coefficient on the variance of hedged returns, evidence that exchange rate volatility is not the whole story. Columns (5) and (6) display a positive and statistically significant coefficient for skewness. In columns (7) and (8), where we include both variance and skewness, the effects are difficult to disentangle, but skewness remains statistically significant. Chi-squared tests strongly reject the joint null hypothesis of zero coefficients for both variance and skewness.

\footnotetext{
10 Excess returns are calculated by subtracting the 1-month U.S. T-bill rate. Expanding the historical sample to begin in January 1997, and thus fully including the Asian financial crises, does not substantively change the results that follow.

11 See Table 1 for the complete list of countries included in the regressions
} 
Overall the results in Table 3 suggest that U.S. investors avoid bond markets that exhibit high historical variance and/or negative skewness. The coefficients in column (4) indicate that if a country were able to lower the variance of its hedged bond returns from the emerging market average to the industrial country average, U.S. investors would increase their holdings by $1.3 \%$ of bonds outstanding. Likewise, column (6) indicates improving skewness from the emerging market average to the industrial country average would attract an increase in holdings of $1.1 \%$ of bonds outstanding. These figures are economically significant compared to end-2001 U.S. holdings of local-currency emerging market debt $(0.4 \%)$ and of developed country bonds $(2.9 \%)$.

By avoiding bonds with highly volatile and negatively skewed returns, U.S. investors are demonstrating an aversion to two measures of risk. But the measures of returns volatility and skewness in Table 3 fail to separate systematic and idiosyncratic sources of these risks. To disentangle the two, we follow Kraus and Litzenberger's (1976) two-stage approach. ${ }^{12}$ First, a three-moment CAPM is estimated for each country's bond returns. Specifically, let $\mathrm{r}_{\mathrm{i}}$ be country $i$ 's bond returns, $\mathrm{r}_{\mathrm{f}}$ the risk-free rate, and $\mathrm{r}_{\mathrm{m}}$ returns on the world bond market. For each country $i$ we estimate the following three-moment CAPM using (at most) 48 months of returns data:

$$
r_{i}-r_{f}=\alpha_{i}+\beta_{i}\left(r_{m}-r_{f}\right)+\gamma_{i}\left(r_{m}-\bar{r}_{m}\right)^{2}+\varepsilon_{i}
$$

The estimated $\beta$ and $\gamma$ coefficients provide measures of systematic variance and skewness, respectively, while the variance of the residual, $\varepsilon_{i}$, proxies for idiosyncratic risk. We use

\footnotetext{
${ }^{12}$ Harvey and Siddique (2000) estimate a conditional version of the three-moment CAPM. With relatively short time series, we opt for the simpler approach of Kraus and Litzenberger (1976).
} 
these in a second-stage regression to investigate whether the degree of U.S. investors' under- or over-weighting in a market depends on systematic or idiosyncratic risk: ${ }^{13}$

$$
\frac{\omega_{i, u s}}{\omega_{i, m}}=\theta_{1}+\theta_{2} \text { Openness }_{i}+\theta_{3} \hat{\beta}_{i}+\theta_{4} \hat{\gamma}_{i}+\theta_{5} \operatorname{var}\left(\hat{\varepsilon}_{i}\right)+\mu_{i}
$$

Under the null hypothesis, systematic variance and skewness of returns are priced and so should not affect (relative) portfolio weights (i.e., $\theta_{3}=\theta_{4}=0$ ). Optimal allocations will not be as easily calculated as in the traditional two-moment CAPM-Athaydes and Flores (2004) and Harvey et al. (2003) show just how complicated they can be-but if expected returns adjust, we should not see a relationship between $\omega_{\mathrm{us}} / \omega_{\mathrm{m}}$ and systematic risk.

Similarly, idiosyncratic risk should not matter because it is diversifiable, although the severe home bias depicted in Table 2 suggests that U.S. investors do not fully diversify.

Results from the second stage regressions are presented in Table 4. Once again, unhedged returns are used in the left panel and hedged returns on the right. The coefficients on the measures of systematic variance and skewness are statistically insignificant throughout Table 4. The finding that portfolio weights are not impacted by measures of systematic risk is consistent with the notion that U.S. investors expect to be rewarded with higher returns for holding higher levels of systematic risk. The coefficient on our measure of idiosyncratic risk, however, is negative and statistically significant throughout Table 4. In theory, idiosyncratic risk does not require a return, therefore this result does not suggest a

\footnotetext{
${ }^{13}$ This regression includes generated regressors, which will cause OLS standard errors to be understated and bias our results toward rejection of the null hypothesis. However, the variance of these generated regressors across countries likely far exceeds the noise in an individual country's estimate, so the estimated $\theta_{\mathrm{i}}$ will be consistent and unbiased. Put another way, there is enough variation between countries that it should not materially affect cross-sectional regressions if we estimate country $i$ 's $\beta$ to be 1.2 when it is truly 1.4.
} 
market failure but rather a failure of U.S. investors to sufficiently diversify. ${ }^{14}$ This appears to give countries an option. They can wait until global investors decide to eliminate home bias, or they can implement policies that are less likely to produce volatile and negatively skewed returns.

\section{Conclusion}

This paper investigates the ability of countries to attract foreign participation in local bond markets. We find evidence that U.S. investors avoid local currency bond markets that have returns with high variance and negative skewness.

High variance and negative skewness are features found predominantly in emerging markets. Is it possible for emerging markets to attract global investors to their local currency bond markets? If the macroeconomic instability that produces the less than desirable returns characteristics owes to external factors, options for emerging economies are limited. However, if the instability owes to domestic policies, as emphasized in Black (1981), the path is clear. Improved policies can lead to returns characteristics that attract global investors. Moreover, such policies can also produce much deeper local bond markets (Burger and Warnock, 2006), which could enable the creation of derivative markets that allow investors to transfer currency risk to those more willing to bear it. ${ }^{15}$

\footnotetext{
${ }^{14}$ It is possible that U.S. investors eliminate country-specific idiosyncratic risk through holdings of other types of assets, such as equities. However, regression results (not shown) indicate this is not the case; the more underweight is a country's bonds in U.S. investors portfolios, the more underweight are its equities.

${ }^{15}$ See Carlton (1984) for a discussion of an existing deep market for the underlying asset as a necessary precondition for successful derivative market development.
} 


\section{References}

Ahearne, A., W. Griever, and F. Warnock, 2004. Information Costs and Home Bias: An Analysis of U.S. Holdings of Foreign Equities. Journal of International Economics 62: 313-336.

Athayde, G. de, and R. Flores, 2004. Finding a Maximum Skewness Portfolio - A General Solution to Three-Moments Portfolio Choice. Journal of Economic Dynamics and Control 28(7): 13351352.

Black, F., 1974. International Capital Market Equilibrium with Investment Barriers. Journal of Financial Economics 1(4): 337-352.

Black, S.W., 1981. The Impact of Changes in the World Economy on Stabilization Policies in Developing Countries in the 1970s. in W.R. Cline and S. Weintraub (eds.) Economic Stabilization in Developing Countries (Brookings Institution, Washington DC.).

Burger, J., and F. Warnock, 2006. Local Currency Bond Markets. IMF Staff Papers (forthcoming).

Carlton, D., 1984. Future Markets: Their Purpose, Their History, Their Growth, and Their Successes and Failures. Journal of Futures Markets 4(3): 237-271.

Cass, D., and J. Stiglitz, 1970. The Structure of Investor Preferences and Asset Returns, and Separability in Portfolio Allocations: A Contribution to the Pure Theory of Mutual Funds. Journal of Economic Theory 2(2): 122-160.

Chen, N., 1991. Financial Investment Opportunities and the Macroeconomy. Journal of Finance 46(2): 529-54.

Cooper, I., and E. Kaplanis, 1986. Costs to Cross-border Investment and International Equity Market Equilibrium. in J. Edwards, J. Franks, C. Mayer and S. Schaefer (eds.), Recent Developments in Corporate Finance. Cambridge: Cambridge University Press,.

Dahlquist, M., L. Pinkowitz, R. Stulz, and R. Williamson, 2003. Corporate Governance and the Home Bias. Journal of Financial and Quantitative Analysis 38(1): 87-110.

Department of Treasury, Federal Reserve Bank of New York, and Board of Governors of the Federal Reserve System, 2003. Report on U.S. Holdings of Foreign Securities as of December 31, 2001.

Eichengreen, B., and R. Hausmann, 2005. Other People's Money: Debt Denomination and Financial Instability in Emerging Market Economies. Chicago: University of Chicago Press.

Erb, C., C. Harvey, and T. Viskanta, 1999. New Perspectives on Emerging Market Bonds. Journal of Portfolio Management 25(2): 83-92.

Goldstein, M., and P. Turner, 2004. Controlling Currency Mismatches in Emerging Markets. Washington, D.C.: Institute for International Economics.

Griever, W., G. Lee, and F. Warnock, 2001. The U.S. System for Measuring Cross-Border Investment in Securities: A Primer with a Discussion of Recent Developments. Federal Reserve Bulletin (October). 
Gwartney, J. and R. Lawson with N. Emerick, 2003. Economic Freedom of the World: 2003 Annual Report. Vancouver: The Fraser Institute. Data retrieved from www.freetheworld.com.

Harvey, C., J. Liechty, M. Liechty, and P. Muller, 2003. Portfolio Selection with Higher Moments. Mimeo, Drexel University (Philadelphia).

Harvey, C., and A. Siddique, 2000. Conditional Skewness in Asset Pricing Tests. Journal of Finance 55(3): 1263-1295.

Ilmanen, A., 1995. Time-varying Expected Returns in International Bond Markets. Journal of Finance 50: 481-506.

Jorion, P., 1991. International Bonds: The Asset Class. in R. Aliber and B. Bruce (eds.) Global Portfolios. Homewood, IL: Business One Irwin.

Karolyi, A. and R. Stulz, 2003. Are assets priced locally or globally?, in G. Constantinides, M. Harris and R. Stulz, eds.: The Handbook of the Economics of Finance, North-Holland Publishers, New York, NY.

Keim, D., and R. Stambaugh, 1986. Predicting Returns in the Stock and Bond Markets. Journal of Financial Economics 17: 357-390.

Kraus, A., and R. Litzenberger, 1976. Skewness Preferences and the Valuation of Risk Assets. Journal of Finance 31(4): 1085-1100.

Levich, R., 2001. International Financial Markets: Prices and Policies (2nd edition). Boston: McGraw-Hill Irwin.

Levich, R., and L. Thomas, 1993. The Merits of Active Currency Risk Management: Evidence from International Bond Portfolios. Financial Analysts Journal 49(5): 63-70.

Levy, H., and Z. Lerman, 1988. The Benefits of International Diversification in Bonds. Financial Analysts Journal 44(5): 56-64.

Lewis, K., 1999. Trying to explain the home bias in equities and consumption. Journal of Economic Literature, 37:571-608.

Stulz, R., 1981. On the Effects of Barriers to International Investment. Journal of Finance, 36: 923934.

Warnock, F., and V. Warnock, 2005. International Capital Flows and U.S. Interest Rates. International Finance Discussion Paper \#840 (Federal Reserve Board). 
Table 1. The Mean, Variance, and Skewness of Historical Returns

The underlying returns data, from JP Morgan's GBI, EMBI Global, and JACI, are monthly from January 1998 through December 2001 and are expressed per annum. For emerging markets, hedged returns are returns on dollar-denominated bonds and unhedged returns are constructed by combining these with exchange rate changes. Aggregates are equally-weighted averages.

\begin{tabular}{|c|c|c|c|c|c|c|}
\hline & Unh & ged US\$ R & urns & Hed & d US\$ Ret & \\
\hline & Mean & Variance & Skewness & Mean & Variance & Skewness \\
\hline Developed Countries & 0.007 & 0.140 & 0.58 & 0.069 & 0.017 & -0.42 \\
\hline Euro Area & 0.006 & 0.137 & 0.67 & 0.069 & 0.016 & -0.44 \\
\hline Austria & 0.004 & 0.140 & 0.60 & 0.066 & 0.014 & -0.47 \\
\hline Belgium & 0.005 & 0.132 & 0.70 & 0.071 & 0.013 & -0.42 \\
\hline Finland & 0.003 & 0.134 & 0.73 & 0.070 & 0.012 & -0.52 \\
\hline France & 0.002 & 0.133 & 0.70 & 0.069 & 0.014 & -0.42 \\
\hline Germany & 0.001 & 0.130 & 0.68 & 0.068 & 0.013 & -0.38 \\
\hline Greece & 0.037 & 0.176 & 0.34 & 0.075 & 0.039 & -0.42 \\
\hline Ireland & 0.000 & 0.139 & 0.76 & 0.068 & 0.017 & -0.35 \\
\hline Italy & 0.004 & 0.130 & 0.74 & 0.068 & 0.012 & -0.44 \\
\hline Netherlands & 0.003 & 0.132 & 0.67 & 0.069 & 0.014 & -0.33 \\
\hline Portugal & 0.003 & 0.133 & 0.73 & 0.068 & 0.012 & -0.61 \\
\hline Spain & 0.004 & 0.131 & 0.72 & 0.069 & 0.012 & -0.42 \\
\hline Other Europe & 0.005 & 0.115 & 0.42 & 0.067 & 0.018 & -0.65 \\
\hline Denmark & 0.005 & 0.117 & 0.74 & 0.066 & 0.011 & -0.74 \\
\hline Norway & -0.004 & 0.126 & 0.41 & & & \\
\hline Sweden & -0.014 & 0.116 & -0.19 & 0.071 & 0.015 & -1.15 \\
\hline Switzerland & -0.003 & 0.140 & 0.77 & & & \\
\hline Great Britain & 0.041 & 0.077 & 0.37 & 0.065 & 0.028 & -0.06 \\
\hline Other Developed & 0.012 & 0.180 & 0.54 & 0.067 & 0.021 & -0.22 \\
\hline Australia & -0.001 & 0.208 & 0.40 & 0.061 & 0.026 & 0.43 \\
\hline Canada & 0.035 & 0.062 & 0.36 & 0.066 & 0.020 & 0.77 \\
\hline Japan & 0.026 & 0.237 & 1.07 & 0.077 & 0.021 & -2.17 \\
\hline New Zealand & -0.013 & 0.213 & 0.33 & 0.065 & 0.016 & 0.10 \\
\hline Emerging Markets & 0.004 & 0.809 & -0.95 & 0.076 & 0.431 & -1.35 \\
\hline Latin America & -0.041 & 1.048 & -1.62 & 0.049 & 0.665 & -1.89 \\
\hline Argentina & -0.218 & 1.369 & -2.22 & -0.218 & 1.369 & -2.22 \\
\hline Brazil & -0.093 & 2.335 & -2.00 & 0.090 & 0.695 & -2.24 \\
\hline Chile & -0.011 & 0.176 & 1.10 & 0.099 & 0.029 & 0.06 \\
\hline Colombia & -0.052 & 0.683 & -1.59 & 0.092 & 0.404 & -1.86 \\
\hline Mexico & 0.080 & 0.470 & -2.49 & 0.110 & 0.164 & -2.74 \\
\hline Peru & 0.046 & 0.939 & -1.64 & 0.104 & 0.759 & -1.73 \\
\hline Venezuela & -0.038 & 1.362 & -2.48 & 0.066 & 1.234 & -2.53 \\
\hline Emerging Asia & 0.073 & 0.926 & -0.59 & 0.088 & 0.399 & -1.00 \\
\hline China & 0.096 & 0.043 & 0.70 & 0.096 & 0.043 & 0.68 \\
\hline India & 0.077 & 0.037 & -1.43 & 0.119 & 0.024 & -0.92 \\
\hline Indonesia & -0.168 & 3.245 & 0.28 & -0.081 & 1.370 & -0.94 \\
\hline Korea & 0.208 & 0.753 & -2.86 & 0.144 & 0.227 & -1.76 \\
\hline Malaysia & 0.104 & 0.615 & 0.13 & 0.098 & 0.352 & -0.38 \\
\hline Philippines & 0.037 & 0.739 & -1.05 & 0.100 & 0.321 & -2.28 \\
\hline Thailand & 0.160 & 1.048 & 0.07 & 0.143 & 0.454 & -1.44 \\
\hline Financial Centers & 0.052 & 0.041 & 0.12 & 0.092 & 0.027 & -0.35 \\
\hline Hong Kong & 0.107 & 0.042 & -0.02 & 0.109 & 0.041 & -0.01 \\
\hline Singapore & -0.003 & 0.040 & 0.26 & 0.076 & 0.013 & -0.69 \\
\hline Emerging Europe & $-\mathbf{0 . 0 7 7}$ & 0.567 & -0.62 & 0.084 & 0.233 & -0.78 \\
\hline Hungary & -0.015 & 0.133 & 0.45 & 0.068 & 0.011 & -0.61 \\
\hline Poland & 0.173 & 0.400 & -0.19 & 0.084 & 0.117 & 0.60 \\
\hline Turkey & -0.388 & 1.169 & -2.12 & 0.100 & 0.571 & -2.34 \\
\hline Other Emerging & -0.007 & 0.696 & -1.46 & 0.092 & 0.427 & -2.55 \\
\hline Morocco & 0.053 & 0.684 & -2.24 & 0.096 & 0.624 & -3.36 \\
\hline South Africa & -0.067 & 0.708 & -0.68 & 0.088 & 0.230 & -1.74 \\
\hline World ex US & 0.006 & 0.483 & -0.20 & 0.072 & 0.240 & -0.92 \\
\hline
\end{tabular}


Table 2. U.S. Investors' Local Currency Foreign Bond Portfolio

U.S. Holdings of local currency bonds are from the December 2001 benchmark survey of U.S. investment in foreign securities, available at www.treas.gov/tic/fpis. Totals include only the 48 countries listed. U.S. holdings of U.S. bonds are formed by subtracting foreigners' holdings of U.S. bonds, as estimated in Warnock and Warnock (2005), from the size of the U.S. bond market. $\mathrm{w}^{\mathrm{US}}$ and $\mathrm{w}^{\mathrm{M}}$ refer to the weight (in percent) in U.S. investors' bond portfolios and the world market portfolio, respectively. The table (which includes U.S. bonds) lists $97.23 \%$ of U.S. investors' overall bond portfolio; not shown is the other $2.77 \%$, which is comprised mainly of foreign-issued dollar-denominated bonds.

\begin{tabular}{|c|c|c|c|c|}
\hline & $\begin{array}{l}\text { U.S. Holdings } \\
\text { (\$ billions) }\end{array}$ & $\mathrm{w}^{\mathrm{US}}$ & $w^{\mathrm{M}}$ & $\mathrm{w}^{\mathrm{US}} / \mathrm{w}^{\mathrm{M}}$ \\
\hline Developed Countries & 150.20 & 1.200 & 41.666 & 0.029 \\
\hline Euro Area & 82.86 & 0.662 & 19.528 & 0.034 \\
\hline Austria & 0.75 & 0.006 & 0.610 & 0.010 \\
\hline Belgium & 2.77 & 0.022 & 0.973 & 0.023 \\
\hline Finland & 0.57 & 0.005 & 0.188 & 0.024 \\
\hline France & 14.70 & 0.117 & 3.637 & 0.032 \\
\hline Germany & 38.15 & 0.305 & 5.756 & 0.053 \\
\hline Greece & 1.38 & 0.011 & 0.330 & 0.033 \\
\hline Ireland & 0.49 & 0.004 & 0.175 & 0.023 \\
\hline Italy & 9.55 & 0.076 & 4.233 & 0.018 \\
\hline Luxumbourg & 0.83 & 0.007 & 0.178 & 0.037 \\
\hline Netherlands & 7.83 & 0.063 & 2.064 & 0.030 \\
\hline Portugal & 0.16 & 0.001 & 0.246 & 0.005 \\
\hline Spain & 5.69 & 0.045 & 1.140 & 0.040 \\
\hline Other Europe & 19.96 & 0.159 & 4.977 & 0.032 \\
\hline Denmark & 2.27 & 0.018 & 0.782 & 0.023 \\
\hline Iceland & 0.00 & 0.000 & 0.023 & 0.000 \\
\hline Norway & 0.41 & 0.003 & 0.150 & 0.022 \\
\hline Sweden & 3.66 & 0.029 & 0.402 & 0.073 \\
\hline Switzerland & 0.11 & 0.001 & 0.494 & 0.002 \\
\hline Great Britain & 13.51 & 0.108 & 3.126 & 0.035 \\
\hline Other Developed & 47.38 & 0.378 & 17.161 & 0.022 \\
\hline Australia & 3.26 & 0.026 & 0.368 & 0.071 \\
\hline Canada & 21.48 & 0.172 & 1.451 & 0.118 \\
\hline Japan & 21.35 & 0.171 & 15.301 & 0.011 \\
\hline New Zealand & 1.29 & 0.010 & 0.042 & 0.246 \\
\hline Emerging Markets & 2.68 & 0.021 & 5.292 & 0.004 \\
\hline Latin America & 0.46 & 0.004 & 1.008 & 0.004 \\
\hline Argentina & 0.07 & 0.001 & 0.118 & 0.005 \\
\hline Brazil & 0.08 & 0.001 & 0.361 & 0.002 \\
\hline Chile & 0.01 & 0.000 & 0.112 & 0.001 \\
\hline Colombia & 0.00 & 0.000 & 0.053 & 0.000 \\
\hline Mexico & 0.29 & 0.002 & 0.320 & 0.007 \\
\hline Peru & 0.00 & 0.000 & 0.008 & 0.000 \\
\hline Venezuela & 0.02 & 0.000 & 0.035 & 0.003 \\
\hline Uruguay & 0.00 & 0.000 & 0.003 & 0.000 \\
\hline Emerging Asia & 0.43 & 0.003 & 3.257 & 0.001 \\
\hline China & 0.00 & 0.000 & 1.014 & 0.000 \\
\hline India & 0.00 & 0.000 & 0.439 & 0.000 \\
\hline Indonesia & 0.01 & 0.000 & 0.156 & 0.000 \\
\hline Korea & 0.25 & 0.002 & 0.902 & 0.002 \\
\hline Malaysia & 0.02 & 0.000 & 0.233 & 0.001 \\
\hline Pakistan & 0.00 & 0.000 & 0.087 & 0.000 \\
\hline Philippines & 0.01 & 0.000 & 0.052 & 0.001 \\
\hline Thailand & 0.03 & 0.000 & 0.112 & 0.002 \\
\hline Taiwan & 0.11 & 0.001 & 0.264 & 0.003 \\
\hline Financial Centers & 0.11 & 0.001 & 0.178 & 0.005 \\
\hline Hong Kong & 0.07 & 0.001 & 0.075 & 0.007 \\
\hline Singapore & 0.04 & 0.000 & 0.103 & 0.003 \\
\hline Emerging Europe & 0.74 & 0.006 & 0.424 & 0.014 \\
\hline Czech & 0.01 & 0.000 & 0.031 & 0.003 \\
\hline Hungary & 0.17 & 0.001 & 0.051 & 0.027 \\
\hline Poland & 0.55 & 0.004 & 0.114 & 0.039 \\
\hline Turkey & 0.00 & 0.000 & 0.228 & 0.000 \\
\hline Other Emerging & 0.94 & 0.007 & 0.424 & 0.018 \\
\hline Israel & 0.49 & 0.004 & 0.260 & 0.015 \\
\hline Morocco & 0.00 & 0.000 & 0.043 & 0.000 \\
\hline South Africa & 0.45 & 0.004 & 0.121 & 0.029 \\
\hline World ex US & 152.9 & 1.22 & 46.96 & 0.026 \\
\hline memo: US bonds & 12,020 & 96.01 & 45.31 & \\
\hline
\end{tabular}




\section{Table 3}

\section{Multivariate Tests of U.S. Investment Using Historical Returns}

OLS regression estimates of U.S. Investment in local-currency-denominated bonds on Openness, detrended stock index (Cycle), and the Mean, Variance, and Skewness of historical excess returns. For information on the underlying returns data, see Table 1 . Openness is an average of the 2000 and 2001 values of the Freedom of the World measure of capital account openness, which ranges from 0 (closed) to 10 (open). Columns (2), (4), (6), and (8) exclude New Zealand. Columns (3) - (8) exclude Switzerland and Norway, for which hedged returns are not available. Results are similar if returns data back to January 1997 are used, with the exception that Skewness becomes significant $(\mathrm{p}=0.07)$ in the unhedged regressions. The $\mathrm{p}$-value, based on robust standard errors, of the two-tailed t-test of equality with zero is reported in parentheses below coefficient estimates. $\chi^{2}(2)$ reports the chi-squared test statistic (and, in parentheses, the p-value) for the test that the coefficients on Variance and Skewness are jointly equal to zero.

\begin{tabular}{|c|c|c|c|c|c|c|c|c|}
\hline & \multicolumn{2}{|c|}{ Unhedged } & \multicolumn{6}{|c|}{ Hedged } \\
\hline & (1) & $(2)$ & (3) & (4) & (5) & (6) & (7) & (8) \\
\hline Mean & $\begin{array}{c}-0.0248 \\
(0.502)\end{array}$ & $\begin{array}{l}-0.0147 \\
(0.901)\end{array}$ & $\begin{array}{l}-0.1635 \\
(0.025)\end{array}$ & $\begin{array}{l}-0.1306 \\
(0.000)\end{array}$ & $\begin{array}{l}-0.0429 \\
(0.262)\end{array}$ & $\begin{array}{l}-0.0265 \\
(0.356)\end{array}$ & $\begin{array}{l}-0.0803 \\
(0.155)\end{array}$ & $\begin{array}{r}-0.0748 \\
(0.085)\end{array}$ \\
\hline Variance & $\begin{array}{c}-0.0078 \\
(0.048)\end{array}$ & $\begin{array}{l}-0.0081 \\
(0.015)\end{array}$ & $\begin{array}{c}-0.0380 \\
(0.000)\end{array}$ & $\begin{array}{r}-0.0323 \\
(0.000)\end{array}$ & & & $\begin{array}{r}-0.0109 \\
(0.382)\end{array}$ & $\begin{array}{r}-0.0141 \\
(0.180)\end{array}$ \\
\hline Skewness & $\begin{array}{c}0.0043 \\
(0.142)\end{array}$ & $\begin{array}{c}0.0040 \\
(0.074)\end{array}$ & & & $\begin{array}{l}0.0151 \\
(0.003)\end{array}$ & $\begin{array}{l}0.0115 \\
(0.005)\end{array}$ & $\begin{array}{l}0.0130 \\
(0.039)\end{array}$ & $\begin{array}{l}0.0088 \\
(0.095)\end{array}$ \\
\hline Openness & $\begin{array}{l}0.0040 \\
(0.118)\end{array}$ & $\begin{array}{l}0.0020 \\
(0.186)\end{array}$ & $\begin{array}{l}0.0040 \\
(0.074)\end{array}$ & $\begin{array}{l}0.0021 \\
(0.082)\end{array}$ & $\begin{array}{c}0.0036 \\
(0.091)\end{array}$ & $\begin{array}{l}0.0021 \\
(0.116)\end{array}$ & $\begin{array}{l}0.0033 \\
(0.133)\end{array}$ & $\begin{array}{l}0.0017 \\
(0.200)\end{array}$ \\
\hline Cycle & $\begin{array}{l}0.0478 \\
(0.212)\end{array}$ & $\begin{array}{l}0.0164 \\
(0.492)\end{array}$ & $\begin{array}{l}0.0485 \\
(0.164)\end{array}$ & $\begin{array}{l}0.0197 \\
(0.350)\end{array}$ & $\begin{array}{l}0.0544 \\
(0.128)\end{array}$ & $\begin{array}{l}0.0263 \\
(0.267)\end{array}$ & $\begin{array}{l}0.0510 \\
(0.160)\end{array}$ & $\begin{array}{l}0.0220 \\
(0.342)\end{array}$ \\
\hline $\begin{array}{l}\mathrm{N} \\
\text { Adj. } \mathrm{R}^{2} \\
\chi^{2}(2)\end{array}$ & $\begin{array}{c}41 \\
0.025 \\
4.827 \\
(0.090)\end{array}$ & $\begin{array}{c}40 \\
0.094 \\
7.461 \\
(0.024)\end{array}$ & $\begin{array}{c}39 \\
0.109\end{array}$ & $\begin{array}{c}38 \\
0.211\end{array}$ & $\begin{array}{c}39 \\
0.159\end{array}$ & $\begin{array}{c}38 \\
0.269\end{array}$ & $\begin{array}{c}39 \\
0.137 \\
13.58 \\
(0.001)\end{array}$ & $\begin{array}{c}38 \\
0.264 \\
15.71 \\
(0.000)\end{array}$ \\
\hline
\end{tabular}




\section{Table 4}

\section{The Roles of Systematic and Idiosyncratic Risk}

OLS regression estimates of U.S. Investment in local-currency-denominated bonds on Openness and, from a three moment CAPM (equation (9), idiosyncractic risk, systematic variance and systematic skewness.

For information on the underlying returns data, see Table 1. Systematic and Idiosyncratic risk measures are calculated using at most 48 months of returns data. Openness is an average of the 2000 and 2001 values of the Freedom of the World measure of capital account openness, which ranges from 0 (closed) to 10 (open). Columns (2) and (4) exclude New Zealand. Columns (3) and (4) exclude Switzerland and Norway, for which hedged returns are not available. The p-value, based on robust standard errors, of the two-tailed ttest of equality with zero is reported in parentheses.

\begin{tabular}{lcc|cc}
\hline & \multicolumn{2}{c}{ Unhedged } & \multicolumn{2}{c}{ Hedged } \\
& $(1)$ & $(2)$ & $(3)$ & $(4)$ \\
Idiosyncratic Risk & -0.0103 & -0.0086 & -0.022 & -0.0171 \\
& $(0.026)$ & $(0.037)$ & $(0.001)$ & $(0.000)$ \\
& & & & \\
Systematic Variance & 0.0106 & 0.0083 & 0.0033 & 0.0041 \\
& $(0.226)$ & $(0.308)$ & $(0.293)$ & $(0.144)$ \\
Systematic Skewness & 0.0007 & -0.0004 & 0.0004 & 0.0003 \\
& $(0.723)$ & $(0.789)$ & $(0.125)$ & $(0.138)$ \\
Openness & & & & \\
& 0.0034 & 0.0017 & 0.0046 & 0.0024 \\
$\mathrm{~N}$ & $(0.171)$ & $(0.370)$ & $(0.069)$ & $(0.080)$ \\
Adj. $\mathrm{R}^{2}$ & 41 & 40 & 39 & 38 \\
\hline
\end{tabular}


Figure 1

\section{Efficient Frontiers for International Bond Portfolios}

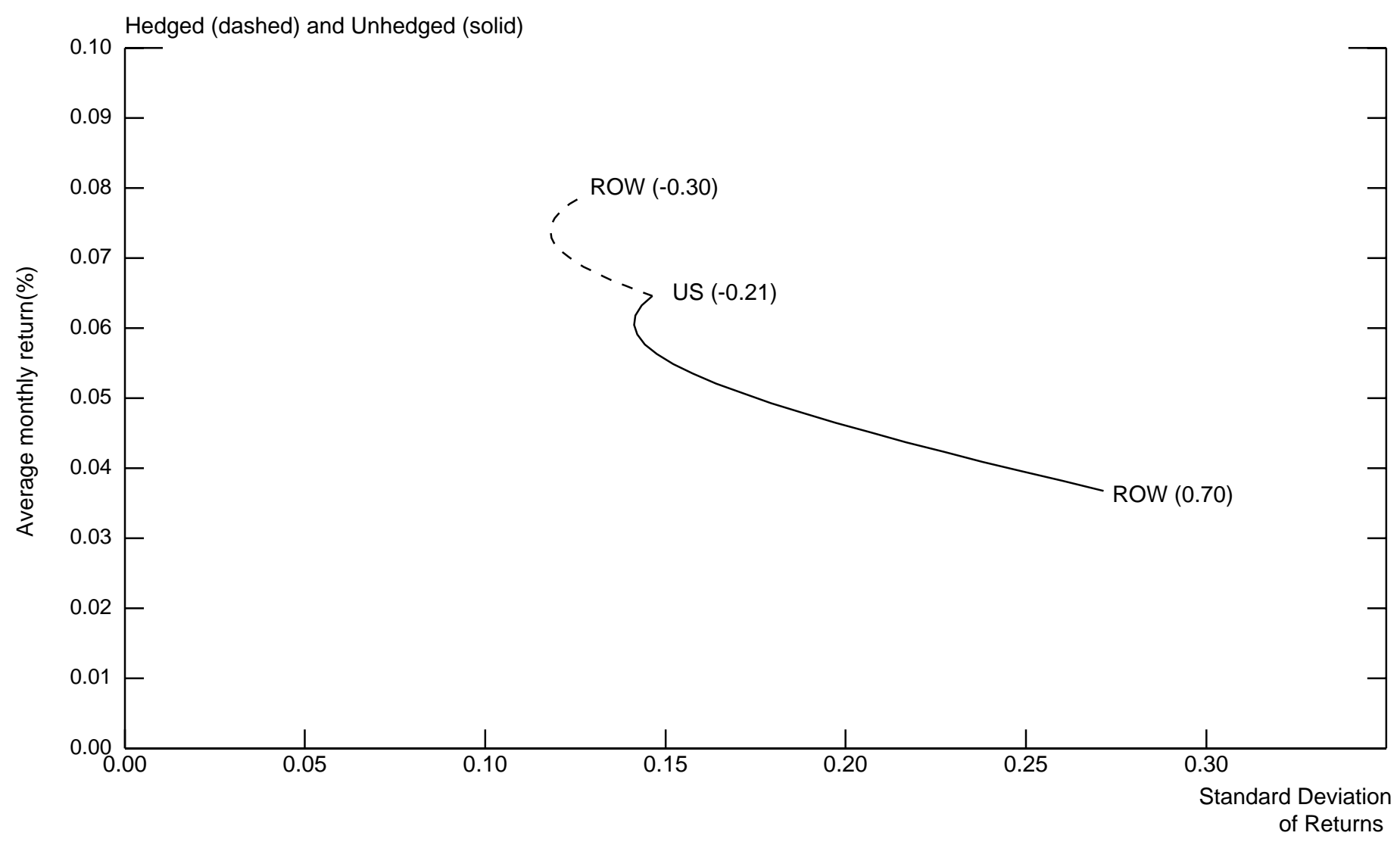

Note. Bond returns are monthly from 1994 to 2001 . Skewness is given in parentheses. 